Jurnal Media Pertanian Vol. 2 No. 2 Tahun 2017 Hal. 55 - 64

Media Komunikasi Hasil Penelitian dan Review Literatur Bidang Ilmu Agronomi

ISSN print $2503-1279$

ISSN online $2581-1606$

\title{
PROSES DEKOMPOSISI \\ BATANG KELAPA SAWIT (Elaeis guineensis Jacq.) METODE REPLANTING SISIPAN DAN PENCINCANGAN
}

\author{
Nasamsir*, Yuza Defitri, Heri Suhermanto** \\ Program Studi Agroteknologi, Fakultas Pertanian Universitas Batanghari \\ Jl. Slamet Riyadi, Broni Jambi, 36122. Telp. +6274160103 \\ ** Alumni Program Studi Agroteknologi Fakultas Pertanian \\ email korenspondensi : nasamsirsamsir@yahoo.co.id
}

\begin{abstract}
This research was carried out in Panca Mulya Village, Sungai Bahar District, Muaro Jambi Regency, Jambi Province since August to September 2017. The material that used was weathering stems of oil palm that already previously replanting by 6 to 7 months, while the tools that used was the Global Positioning System (GPS) with Garmin GPSmap $78 s$ as its brand, plastic bag, holding tool, camera, and stationery. This research was carried out by survey methods applying. Samples was collected from the replanting areas of both underplanting and chipping method, respectively 2 blocks with 3 locations each block had $200 \mathrm{~m}$ distance to North direction with $0.2 \mathrm{~kg}$ weight. Secondary data was collected from a company and Indonesian Agency for Meteorological, Climatological and Geophysics (Badan Meteorologi, Klimatologi, dan Geofisika or simply BMKG) while primary data was an interviews with farmers using a questionnaire. The collected data were : general description of research location, rainfall, temperature, humidity, soil acidity, $C-N$ ratio of oil palm stem both before and after decomposition, from the replanting of both underplanting and chipping methods. The result of this study showed that $C-N$ ratio of oil palm stem before decomposition was 58.42, $C-N$ ratio of oil palm stem decomposition that replanting with underplanting method was 37.18, and the average $C-N$ ratio of chipping method was 14.24. Be equaling with the compost quality specifications on Indonesian national Standar (Standar Nasional Indonesia (SNI) 19-7030-2004, so C/N value of decomposition process of oil palm stem that replanting by chipping method was already meet this standard with 10 to 20 as a $\mathrm{C} / \mathrm{N}$ grade.
\end{abstract}

Keywords ; $C-N$ ratio, oil palm, replanting method

\begin{abstract}
Abstrak
Penelitian ini dilaksanakan di desa Panca Mulya, kecamatan Sungai Bahar, kabupaten Muaro Jambi, Jambi pada bulan Agustus sampai September 2017. Bahan yang digunakan adalah hasil pelapukan batang Kelapa sawit yang sudah direplanting 6 sampai 7 bulan sebelumnya, sedangkan alat-alat yang digunakan adalah Global Positioning System (GPS) merek Garmin GPSmap 78s, kantung plastik, alat pengambil bahan, kamera, dan alat tulis. Penelitian ini dilaksanakan dengan metode survey, sampel dikumpulkan dari areal replanting metode sisipan dan matode pencincangan, masing-masing 2 blok pada 3 titik setiap blok jarak $200 \mathrm{~m}$ arah utara dengan berat $0.2 \mathrm{~kg}$. Data sekunder dikumpulkan dari perusahaan atau BMKG dan wawancara dengan petani menggunakan kuisioner. Data yang dikumpulkan adalah ; informasi umum lokasi penelitian, curah hujan, suhu, kelembaban,
\end{abstract}


Jurnal Media Pertanian Vol. 2 No. 2 Tahun 2017 Hal. 55 - 64

Media Komunikasi Hasil Penelitian dan Review Literatur Bidang Ilmu Agronomi

ISSN print $2503-1279$

ISSN online $2581-1606$

$\mathrm{pH}$ tanah, rasio C-N batang Kelapa sawit sebelum dekomposisi, serta rasio C-N hasil dekomposisi.dari replanting metode sisipan dan pencincangan. Hasil penlitian menunjukkan nisbah C-N batang Kelapa sawit di daerah penelitian sebelum dekomposisi 58,42, rasio C-N dekomposisi batang Kelapa sawit replanting dengan metode sisipan ratarata 37.18, dan metode pencincangan rata-rata 14,24. Bila disetarakan dengan spesifikasi kualitas kompos SNI 19-7030-2004, nilai C/N proses dekomposisi batang Kelapa sawit hasil replanting metode pencincangan sudah memenuhi standar dengan nilai $\mathrm{C} / \mathrm{N} 10$ sampai 20.

\section{Kata kunci ; rasio $C-N$, Kelapa sawit, metode replanting}

\section{PENDAHULUAN}

Dalam perekonomian Indonesia, komoditas Kelapa sawit memegang peranan yang cukup strategis karena komoditas ini punya prospek yang cerah sebagai sumber devisa. Di samping itu, minyak sawit merupakan bahan baku utama minyak goreng yang banyak dipakai diseluruh dunia, sehingga secara terus-menerus mampu menjaga stabilitas harga minyak sawit. Komoditas ini pun mampu pula menciptakan kesempatan kerja yang luas dan meningkatkan kesejahteraan masyarakat (Risza,1994).

Jambi merupakan salah satu sentra penghasil Kelapa sawit di Indonesia. Luas areal, produksi dan produktivitas Kelapa sawit dari tahun 2009 sampai dengan 2013 dapat dilihat pada Tabel 1, pertanaman Kelapa sawit di provinsi Jambi terus mengalami peningkatan yaitu pada tahun 2009 luas areal tanaman Kelapa sawit 489.384 hektar, dengan produksi 1.265.789 ton, kemudian meningkat menjadi 593.433 hektar, dan produksinya mencapai 1.555.697 ton, pada tahun 2013 .

Tabel 1. Luas areal, produksi dan produktivitas tanaman Kelapa sawit di provinsi Jambi dari tahun 2009 Sampai tahun 2013

\begin{tabular}{ccccccc}
\hline \multirow{4}{*}{ Tahun } & \multicolumn{3}{c}{ Luas Areal (ha) } & Produksi & \multirow{2}{*}{$\begin{array}{c}\text { Produktivitas } \\
\text { ( } \mathrm{kg} / \mathrm{ha})\end{array}$} \\
\cline { 2 - 5 } & TBM & TM & TTM/TR & Jumlah & & \\
\hline 2009 & 113.954 & 371.808 & 3.622 & 489.384 & 1.265 .789 & 3.404 \\
2010 & 107.022 & 402.221 & 4.716 & 513.959 & 1.392 .293 & 3.462 \\
2011 & 110.259 & 417.304 & 4.730 & 532.293 & 1.426 .081 & 3.417 \\
2012 & 150.998 & 433.405 & 4.937 & 589.340 & 1.472 .852 & 3.398 \\
2013 & 143.172 & 444.588 & 5.673 & 593.433 & 1.555 .697 & 3.499 \\
\hline
\end{tabular}

Sumber : Dinas Perkebunan Provinsi Jambi, 2013

Keterangan :

TBM : Tanaman Belum Menghasilkan

TM : Tanaman Menghasil

TTM : Tanaman Tidak Menghasilkan

TR : Tanaman Rusak 
Jurnal Media Pertanian Vol. 2 No. 2 Tahun 2017 Hal. 55 - 64

Media Komunikasi Hasil Penelitian dan Review Literatur Bidang Ilmu Agronomi ISSN print $2503-1279$ ISSN online $2581-1606$

Salah satu sentra produksi Kelapa sawit provinsi Jambi terdapat di kabupaten Muaro Jambi. Berdasarkan data Dinas Perkebunan Provinsi Jambi, produksi Kelapa sawit kabupaten Muaro Jambi tahun 2015 sebesar 188.534 ton, produksi ini merupakan produksi tertinggi dari semua kabupaten yang ada di provinsi Jambi. Kecamatan Sungai Bahar Tengah merupakan salah satu penghasil sawit terbesar di kabupaten Muaro Jambi dengan luas lahan pada tahun 2015 sebesar 3147 hektar, luas lahan tertinggi terdapat di desa Marga Mulya sebesar 505 hektar, kemudian desa Panca Mulya 428 hektar (BPS Provinsi Jambi, 2016).

Umur ekonomis tanaman Kelapa sawit adalah sekitar 25 tahun,tanaman Kelapa sawit yang melewati umur ekonomisnya harus segera diremajakan untuk memperbaiki produktivitas yang umumnya sudah menurun tajam. Standar produktivitas yang biasanya dijadikan patokan masa peremajaan adalah sekitar 14 ton TBS per hektar per tahun. Selain produktivitas, efektivitas panen dan kerapatan tanaman menjadi pertimbangan lain dalam penentuan masa peremajaan. Efektivitas panen akan rendah apabila ketinggian pohon Kelapa sawit telah melebihi 12 meter. Selain itu, peremajaan perlu dilakukan apabila kerapatan tanaman kurang dari 80 pohon per hektar. Hal ini dilakukan karena umumnya kondisi tanaman sudah tidak ekonomis (Sutarta,2015).

Dalam meningkatkan produksi dan produktivitas tanaman Kelapa sawit di kecamatan Sungai Bahar, perlu dilakukan kegiatan revitalisasi dalam upaya percepatan pengembangan perkebunan rakyat melalui perluasan, peremajaan dan rehabilitasi tanaman perkebunan.Salah satu aspek revitalisasi yang cukup penting yakni peremajaan atau replanting.

Proses peremajaan dapat dilakukan menggunakan beberapa metode, setiap metode memiliki keuntungan dan kelemahan. Setiap perusahaan akan menetapkan metode replanting dengan pertimbangan ekonomi dan sanitasi lingkungan. Metode yang sering digunakan adalah dengan cara pencincangan batang (chipping) dan sisipan untuk sanitasi terhadap serangan $O$. rhinoceros, preventif serangan penyakit busuk pangkal batang Ganoderma boninanse, dan sebagai sumber bahan organik bagi tanaman Kelapa sawit.

Kelebihan dari peremajaan dengan metode sisipan (underplanting) adalah adanya kesempatan bagi pekebun untuk tetap memperoleh pendapatan dari tanaman tua yang belum ditumbang, tetapi penerapan sistem ini mengakibatkan terganggunya pertumbuhan tanaman muda, meningkatnya serangan kumbang tanduk, berkembangnya penyakit Ganoderma, dan lambatnya terjadi dekomposisi bahan organik (Permentan RI, 2016).

Peremajaan tanaman Kelapa sawit penumbangan serempak yang diikuti dengan pencincangan batang (chipping) memiliki keunggulan,yaitu pengolahan tanah lebih intensif sehingga persiapan lahan menjadi lebih baik sehingga media tanam menjadi lebih ideal bagi tanaman. Pencincangan batang dan penanaman tanaman kacangan bermanfaat untuk mempercepat laju pelapukan (dekomposisi), menjaga kelembaban tanah, menekan resiko serangan hama O.rhinoceros, dan mengurangi penyebaran penyakit Ganoderma sp.(Permentan RI, 2016).

Pencincangan atau penggilingan bahan baku kompos yang berukuran besar agar ukurannya menjadi lebih kecil akan mempercepat proses pengomposan (dekomposisi bahan organik). Akan tetapi, bahan baku yang berukuran terlalu kecil akan menyebabkan rongga udara berkurang karena timbunan menjadi lebih rapat dan ketersediaan oksigen berkurang 
Jurnal Media Pertanian Vol. 2 No. 2 Tahun 2017 Hal. 55 - 64

Media Komunikasi Hasil Penelitian dan Review Literatur Bidang Ilmu Agronomi

ISSN print $2503-1279$

ISSN online $2581-1606$

sehingga mikroorganisme tidak dapat bekerja secara optimal (Murbandono., 2009). Menurut Nurhidayati, dkk. (2008), pengurangan ukuran partikel residu dapat membantu memecahkan dinding sel yang mengandung lignin dan lapisan luar yang mengandung wax, sehingga mengekspos lebih siap sel-sel dan jaringan untuk terdekomposisi.

Kecepatan dekomposisi bahan organik ditunjukan oleh perubahan imbangan $\mathrm{C} / \mathrm{N}$. Selama proses mineralisasi, imbangan $\mathrm{C} / \mathrm{N}$ bahan-bahan yang banyak mengandung $\mathrm{N}$ akan berkurang menurut waktu. Kecepatan kehilangan $\mathrm{C}$ lebih tinggi dari $\mathrm{N}$ sehingga diperoleh imbangan $\mathrm{C} / \mathrm{N}$ yang lebih rendah (10-20). Apabila imbangan $\mathrm{C} / \mathrm{N}$ sudah mencapai angka tersebut, artinya proses dekomposisi sudah mencapai tingkat akhir atau kompos sudah matang. Menurut SNI 19-7030-2004, spesifikasi kualitas kompos yang berasal dari sampah organik adalah adalah apa nilai C/N 10 sampai 20.

Berdasarkan uraian yang dikemukakan di atas, maka penulis tertarik untuk melakukan penelitian mengenai perbedaan proses dekomposisi batang Kelapa sawit metode replanting sisipan dan metode pencincangan.

\section{METODE PENELITIAN}

Penelitian ini dilaksanakan di desa Panca Mulya, kecamatan Sungai Bahar, kabupaten Muaro Jambi provinsi Jambi pada bulan Agustus sampai September 2017

Bahan yang digunakan dalam penelitian ini adalah hasil pelapukan batang Kelapa sawit yang sudah direplanting 6 sampai 7 bulan sebelumnya, sedangkan alat-alat yang digunakan adalah Global Positioning System (GPS) merek Garmin GPSmap 78s, kantung plastik, alat untuk mengambil bahan, kamera, dan alat tulis

Penelitian ini dilaksanakan dengan metode survey, sampel hasil pelapukan batang Kelapa sawit dikumpulkan dari areal replanting metode sisipan dan matode pencincangan, masing-masing 2 blok. Sampel dikumpulkan pada 3 titik untuk setiap blok dengan jarak $200 \mathrm{~m}$ arah utara menggunakan GPS. Berat sampel setiap titik $0.2 \mathrm{~kg}$. Data sekunder dikumpulkan dari perusahaan atau instansi terkait (BMKG). Untuk menggali informasi umum kebun, dilakukan wawancara menggunakan daftar pertanyaan (kuisioner).

Data yang dikumpulkan pada penelitian ini meliputi ; informasi umum lokasi penelitian, data curah hujan, suhu, kelembaban, dan $\mathrm{pH}$ tanah, dan rasio $\mathrm{C}-\mathrm{N}$ hasil pelapukan batang tanaman Kelapa sawit

Data hasil pengukuran rasio $\mathrm{C}-\mathrm{N}$ dan data sekunder kemudian dianalisis secara deskriptif dan ditampilkan dalam bentuk tabel. Untuk melihat perbedaan rasio C-N antar metode replanting dilakukan analisis inferensi menggunakan uji-t.

\section{Informasi Umum Lokasi Penelitian}

\section{HASIL DAN PEMBAHASAN}

Secara administratif desa Panca Mulya terdiri dari 2 (dua) dusun, yaitu dusun Jati Mulyo meliputi 6 (enam) rukun tetangga, dan dusun Sari Mulyo 6 (enam) rukun tetangga dengan luas wilayah seluruhnya 1.700 hektar membentang dari utara ke selatan sebagian besar adalah perkebunan kelapa sawit dan permukiman penduduk. Lokasi penelitian termasuk kecamatan Sungai Bahar, kabupaten Muaro Jambi yang merupakan lokasi kebun plasma dari PTPN Perkebunan VI Sungai Bahar. Masing-masing petani memiliki lahan seluas 2 hektar. Kebun plasma ini rata-rata sudah memiliki umur 20 tahun setelah tanam. 
Jurnal Media Pertanian Vol. 2 No. 2 Tahun 2017 Hal. 55 - 64

Media Komunikasi Hasil Penelitian dan Review Literatur Bidang Ilmu Agronomi

ISSN print $2503-1279$

ISSN online $2581-1606$

Topografi desa Panca Mulya adalah dataran rendah dengan kondisi tanah lempung berpasir. Suhu udara rata-rata $26^{\circ} \mathrm{C}-28{ }^{\circ} \mathrm{C}$ dengan curah hujan rata-rata $2.520 \mathrm{~mm}$ per tahun. Jarak tempuh ke pusat pemerintahan $8 \mathrm{~km}$ ( ibu kota kecamatan Sungai Bahar), sedangkan ke ibu kota kabupaten Muaro Jambi $137 \mathrm{~km}$ dan $90 \mathrm{~km}$ ke ibu kota provinsi Jambi.

Batas-batas wilayah lokasi penelitian adalah sebelah timur berbatasan dengan desa Tanjung Harapan, sebelah barat berbatasan dengan desa Marga Manunggal Jaya, sebelah utara berbatasan dengan desa Berkah dan sebelah selatan berbatasan dengan desa Bukit Subur.

Tanaman Kelapa sawit yang ditanam pada kebun lokasi penelitian adalah jenis Tenera yang berasal dari PPKS Medan. Populasi tanaman per hektar sebanyak 136 pohon per hektar. Petani selalu melakukan pemupukan dan pemberantasan hama dan penyakit menggunakan pestisida kimia buatan.

Umur petani sampel yang melakukan usaha tani adalah 45 sampai 50 tahun dengan tingkat pendidikan rata-rata tamat SD. Bila ditinjau dari segi umur, kemampuan petani untuk melakukan pengelolaan usaha tani sudah mulai menurun. Tingkat pendidikan petani tidak terlalu mempengaruhi kemampuan pengelolaan usaha tani Kelapa sawit, karena sejak dari awal menjadi peserta plasma mereka selalu didampingi dan diberi petunjuk oleh pihak perusahaan.

Curah hujan,Hari hujan, Rata-rata suhu dan Kelembaban udara

Data curah hujan dan hari hujan kabupaten Muaro Jambi 2016 dapat dilihat pada Tabel 2.

Tabel 2. Jumlah Curah hujan dan Hari hujan menurut bulan di Kabupaten Muaro Jambi 2016

\begin{tabular}{lcc}
\hline \multicolumn{1}{c}{ Bulan } & Curah Hujan $\left(\mathbf{m m}^{\mathbf{3}}\right)$ & Hari Hujan \\
\hline Januari & $(2)$ & $(3)$ \\
Februari & 244,6 & 22 \\
Maret & 245,9 & 18 \\
April & 236,5 & 25 \\
Mei & 138,2 & 17 \\
Juni & 267,7 & 18 \\
Juli & 79,4 & 15 \\
Agustus & 71,4 & 6 \\
September & 192,3 & 11 \\
Oktober & 55,5 & 16 \\
November & 158,8 & 18 \\
Desember & 430,8 & 24 \\
Jumlah & 125,8 & 15 \\
Rata-rata & $\mathbf{2 3 0 9}$ & $\mathbf{2 0 5}$ \\
\hline
\end{tabular}

Sumber : BMKG, Stasiun Klimatologi Muaro Jambi (2017).

Dari tabel tersebut terlihat bahwa rata-rata curah hujan tertinggi pada tahun 2016 terjadi pada bulan Nopember yaitu $430,8 \mathrm{~mm}^{3}$, kemudian diikuti oleh curah hujan bulan 
Jurnal Media Pertanian Vol. 2 No. 2 Tahun 2017 Hal. 55 - 64

Media Komunikasi Hasil Penelitian dan Review Literatur Bidang Ilmu Agronomi

ISSN print $2503-1279$

ISSN online $2581-1606$

Januari, Februari, Maret, dan Mei. Curah hujan terendah terjadi pada bulan September 2016 yaitu sebanyak $55,5 \mathrm{~mm}^{3}$.

Menurut klasifikasi Schmidt-Ferguson, bulan kering (BK) adalah bulan dengan curah hujan kurang dari $60 \mathrm{~mm}^{3}$, bulan lembab (BL) adalah bulan dengan curah hujan 60 sampai $100 \mathrm{~mm}^{3}$, dan bulan basah (BB) adalah bulan dengan curah hujan lebih dari 100 $\mathrm{mm}^{3}$ per bulan.

Dari data pada Tabel 2 di atas, pada tahun 2016 di kabupaten Muaro Jambi terjadi bulan kering pada bulan September. Bulan basah terjadi pada bulan selain dari bulan Juni, Juli dan September. Rata-rata hari hujan kabupaten Muaro Jambi tahun 2016 terbanyak adalah pada bulan Maret yaitu 25 hari hujan, kemudian diikuti bulan Januari dan Nopember 2016. Rata-rata hari hujan terendah adalah pada bulan Juli, yaitu 6 hari hujan.

Rata-rata suhu dan kelembaban udara kabupaten Muaro Jambi tahun 2016 disajikan pada Tabel 3

Tabel 3. Rata-rata suhu dan kelembaban udara kabupaten Muaro Jambi tahun 2016

\begin{tabular}{|c|c|c|c|c|c|c|}
\hline \multirow{2}{*}{ Bulan } & \multicolumn{3}{|c|}{ Suhu Udara $\left({ }^{\circ} \mathrm{C}\right)$} & \multicolumn{3}{|c|}{ Kelembaban Udara (\%) } \\
\hline & Maks & Min & Rata-rata & Maks & Min & Rata-rata \\
\hline (1) & & (2) & & \multicolumn{2}{|c|}{ (3) } & (4) \\
\hline Januari & 31,7 & 24,1 & 26,8 & 97 & 71 & 87 \\
\hline Februari & 31,2 & 23,7 & 26,7 & 97 & 72 & 86 \\
\hline Maret & 32,9 & 24,2 & 27,2 & 96 & 74 & 87 \\
\hline April & 33,8 & 24,3 & 27,6 & 96 & 67 & 85 \\
\hline Mei & 33,1 & 24,7 & 28,0 & 95 & 69 & 85 \\
\hline Juni & 32,5 & 24,0 & 27,3 & 96 & 67 & 85 \\
\hline Juli & 32,9 & 23,6 & 27,3 & 95 & 64 & 82 \\
\hline Agustus & 33,4 & 23,7 & 27,7 & 94 & 61 & 80 \\
\hline September & 32,4 & 23,5 & 27,2 & 96 & 64 & 82 \\
\hline Oktober & 32,0 & 23,7 & 27,0 & 96 & 69 & 86 \\
\hline November & 31,3 & 23,7 & 26,8 & 97 & 73 & 87 \\
\hline Desember & 31,3 & 24,0 & 27,1 & 96 & 72 & 86 \\
\hline
\end{tabular}

Sumber: BMKG, Stasiun Klimatologi Muaro Jambi (2017).

Dari tabel di atas terlihat rata-rata suhu maksimum kabupaten Muaro Jambi tahun 2016 berkisar $31^{\circ} \mathrm{C}$ sampai $33^{\circ} \mathrm{C}$ dengan suhu minimum berkisar $23^{\circ} \mathrm{C}$ sampai $24^{0} \mathrm{C}$. Kelembaban udara maksimum $94 \%$ sampai $97 \%$ dengan kelembaban minimum berkisar $61 \%$ sampai $74 \%$.

\section{Suhu, Kelembaban, dan pH tanah Lokasi Penelitian}

Suhu, kelembaban dan $\mathrm{pH}$ tanah lokasi penelitian ditampilkan pada Tabel 4 Tabel tersebut menunjukkan bahwa rata-rata suhu di lokasi replanting metode sisipan $30^{\circ} \mathrm{C}$. Kondisi ini akan mempengaruhi tingkat kelembaban, terlihat bahwa rata-rata tingkat kelembaban lokasi pengambilan sampel cukup tinggi $(41 \%)$. Tanah di lokasi penelitian tergolong tanah masam, dengan rata-rata $\mathrm{pH} 4,9 . \mathrm{pH}$ ini akan mempengaruhi aktivitas mikroorganisme pengurai. 
Jurnal Media Pertanian Vol. 2 No. 2 Tahun 2017 Hal. 55 - 64

Media Komunikasi Hasil Penelitian dan Review Literatur Bidang Ilmu Agronomi

ISSN print $2503-1279$

ISSN online $2581-1606$

Tabel 4. Suhu, kelembaban dan $\mathrm{pH}$ tanah lokasi penelitian replanting metode sisipan

\begin{tabular}{|c|c|c|c|c|c|c|c|c|}
\hline \multirow[b]{2}{*}{ No. } & \multirow[b]{2}{*}{ Faktor } & \multicolumn{3}{|c|}{ Blok I } & \multicolumn{3}{|c|}{ Blok II } & \multirow[b]{2}{*}{ Rata-rata } \\
\hline & & Titik & Titik & Titik & Titik & Titik & Titik & \\
\hline 1 & Suhu $\left({ }^{0} \mathrm{C}\right)$ & $\frac{1}{31}$ & $\frac{2}{29}$ & $\frac{3}{26}$ & $\frac{1}{33}$ & $\frac{2}{31}$ & $\frac{5}{28}$ & 30 \\
\hline 2 & Kelembaban (\%) & 45 & 41 & 39 & 40 & 38 & 43 & 41 \\
\hline 3 & $\mathrm{pH}$ tanah & 4.7 & 5.3 & 4.5 & 5.1 & 4.8 & 5.1 & 4.9 \\
\hline
\end{tabular}

Sumber : Data hasil pengukuran di lapangan

Suhu, kelembaban dan $\mathrm{pH}$ tanah lokasi penelitian replanting metode pencincangan ditampilkan pada tabel di bawah ini.

Tabel 5. Suhu, kelembaban dan $\mathrm{pH}$ tanah lokasi penelitian replanting metode pencincangan

\begin{tabular}{llccccccc}
\hline & & \multicolumn{3}{c}{ Blok I } & \multicolumn{3}{c}{ Blok II } & \\
\cline { 3 - 7 } No. & Faktor & Titik & Titik & Titik & Titik & Titik & Titik & Rata-rata \\
& & 1 & 2 & 3 & 1 & 2 & 3 & \\
\hline 1 & Suhu $\left({ }^{0} \mathrm{C}\right)$ & 26 & 25 & 26 & 30 & 27 & 27 & 27 \\
2 & Kelembaban $(\%)$ & 31 & 36 & 37 & 38 & 35 & 32 & 35 \\
3 & pH tanah & 6.2 & 6.1 & 5.8 & 5.4 & 6.2 & 6.3 & 6.0 \\
\hline
\end{tabular}

Sumber : Data hasil pengukuran di lapangan

Rata-rata suhu lokasi pengambilan sampel replanting metode pencincangan $27^{\circ} \mathrm{C}$ dengan kelembaban udara rata-rata $35 \%$. $\mathrm{pH}$ tanah rata-rata 6 , dengan rata-rata $\mathrm{pH}$ mendekati netral ini laju dekomposisi akan lebih cepat dibanding lokasi metode sisipan.

Dekomposisi Batang Kelapa Sawit

Proses dekomposisi batang Kelapa sawit diukur menggunakan parameter rasio C-N (C/N). Hasil analisis $\mathrm{C} / \mathrm{N}$ disajikan pada tabel di bawah ini.

Hasil analisis C/N batang Kelapa sawit ditunjukkan pada Tabel 6

Tabel 6 . Hasil analisis $\mathrm{C} / \mathrm{N}$ batang Kelapa sawit

\begin{tabular}{lccccc}
\hline \multirow{2}{*}{ Parameter Uji } & \multirow{2}{*}{ Satuan } & \multicolumn{4}{c}{ Hasil Uji } \\
\cline { 3 - 6 } & & sampel 1 & sampel 2 & sampel 3 & Rata-rata \\
\hline N-Organik & $\%$ & 1.15 & 1.21 & 1.32 & 1.23 \\
C-Organik & $\%$ & 68.12 & 74.11 & 72.31 & 71.51 \\
C/N & & 59.23 & 61.25 & 54.78 & 58.42 \\
\hline
\end{tabular}

Sumber : Data hasil pengukuran di laboratorium

Tabel 6 menunjukkan batang Kelapa sawit di daerah penelitian mempunyai nisbah C-N = 58,42 Menurut Sutanto (2002), bila ketersediaan karbon berlebihan (C/N >45) jumlah nitrogen sangat terbatas, maka merupakan faktor pembatas pertumbuhan mikroorganisme, proses dekomposisi menjadi terhambat karena kelebihan karbon harus dibakar atau dibuang 
Jurnal Media Pertanian Vol. 2 No. 2 Tahun 2017 Hal. 55 - 64

Media Komunikasi Hasil Penelitian dan Review Literatur Bidang Ilmu Agronomi

ISSN print $2503-1279$

ISSN online $2581-1606$

oleh mikroorganisme dalam bentuk $\mathrm{CO} 2$. Nisbah $\mathrm{C}-\mathrm{N}$ yang cukup besar juga menunjukkan bahwa bahan tersebut sukar terdekomposisi.

Hasil analisis $\mathrm{C} / \mathrm{N}$ batang Kelapa sawit replanting metode sisipan dirangkum pada tabel di bawah ini.

Tabel 7. Hasil Analisis C/N Batang Kelapa Sawit Replanting Metode Sisipan

\begin{tabular}{|c|c|c|c|c|c|c|c|c|c|c|}
\hline \multirow{3}{*}{$\begin{array}{c}\text { Parameter } \\
\text { Uji }\end{array}$} & \multirow{3}{*}{ Satuan } & \multicolumn{8}{|c|}{ Hasil Uji } & \multirow{3}{*}{$\begin{array}{c}\text { Rata- } \\
\text { rata }\end{array}$} \\
\hline & & \multicolumn{4}{|c|}{ Blok I } & \multicolumn{4}{|c|}{ Blok II } & \\
\hline & & Ttk 1 & Ttk 2 & Ttk 3 & $\begin{array}{c}\text { Rata- } \\
\text { rata }\end{array}$ & Ttk 1 & Ttk 2 & Ttk 3 & $\begin{array}{c}\text { Rata- } \\
\text { rata }\end{array}$ & \\
\hline N-Organik & $\%$ & 1.32 & 1.28 & 1.21 & 1.27 & 1.19 & 1.45 & 2.15 & 1.60 & 1,43 \\
\hline C-Organik & $\%$ & 51.15 & 52.11 & 50.67 & 51.31 & 50.24 & 51.18 & 52.13 & 51.18 & 51,24 \\
\hline $\mathrm{C} / \mathrm{N}$ & $\%$ & 38.75 & 40.71 & 41.88 & 40.45 & 42.22 & 35.30 & 24.25 & 33.92 & 37,18 \\
\hline
\end{tabular}

Sumber : Data hasil pengukuran di laboratorium

Tabel di atas menunjukkan bahwa rasio C-N batang Kelapa sawit replanting dengan metode sisipan berkisar antara 25 sampai 42 dengan rata-rata 37.18. Rata-rata $\mathrm{C} / \mathrm{N}$ ini menunjukkan bahwa proses dekomposisi belum sempurna atau matang.

Hasil analisis $\mathrm{C} / \mathrm{N}$ batang Kelapa sawit replanting metode pencincangan ditampilkan pada Tabel 8, rata-rata nilai $\mathrm{C} / \mathrm{N}$ batang Kelapa sawit dari replanting metode pencincangan 14,24 , nilai $\mathrm{C} / \mathrm{N}$ ini lebih rendah dari rata-rata nilai $\mathrm{C} / \mathrm{N}$ replanting metode sisipan $(37,18)$. Rendahnya nilai $\mathrm{C} / \mathrm{N}$ batang Kelapa sawit dari replanting metode pencincangan ini disebabkan oleh terjadinya perubahan imbangan $\mathrm{C}$ dengan $\mathrm{N}$. Carbon yang ada pada bahan organik batang Kelapa sawit telah dirombak oleh dekomposer menjadi $\mathrm{N}$ yang ditunjukkan oleh tingginya nilai $\mathrm{N}$ organik dibanding metode sisipan.

Berbeda dengan kondisi hasil dekomposisi metode sisipan, hasil dekomposisi batang Kelapa sawit metode pencincangan sudah menghasilkan kematangan kompos yang sesuai dengan standarisasi karakteristik kompos. Menurut Nurhidayati, dkk.(2008), standar karakteristik kematangan kompos adalah bila nilai $\mathrm{C} / \mathrm{N}$ kecil dari 25 .

Tabel 8. Hasil Analisis C/N Batang Kelapa Sawit Replanting Metode Pencincangan

\begin{tabular}{lcccccccccc}
\hline & & \multicolumn{1}{c}{ Hasil Uji } & \multicolumn{1}{c}{ Blok II } \\
\cline { 3 - 10 } $\begin{array}{c}\text { Parameter } \\
\text { Uji }\end{array}$ & Satuan & \multicolumn{1}{c}{ Blok I } \\
\cline { 3 - 10 } & & Ttk 1 & Ttk 2 & Ttk 3 3 & $\begin{array}{c}\text { Rata- } \\
\text { rata }\end{array}$ & Ttk 1 & Ttk 2 & Ttk 3 & $\begin{array}{c}\text { Rata- } \\
\text { rata }\end{array}$ \\
\hline N-Organik & $\%$ & 3.14 & 3.22 & 4.11 & 3.49 & 3.56 & 3.62 & 4.22 & 3.80 & 3,64 \\
C-Organik & $\%$ & 50.65 & 51.15 & 51.72 & 51.17 & 50.98 & 52.11 & 51.22 & 51.44 & 51,30 \\
C/N & $\%$ & 16.13 & 15.89 & 12.58 & 14.87 & 14.32 & 14.40 & 12.14 & 13.62 & 14,24 \\
\hline
\end{tabular}

Sumber : Data hasil pengukuran di laboratorium

Berdasarkan hasil analisis statistika menggunakan uji-t, dapat disimpulkan bahwa ada perbedaan laju dekomposisi antara replanting metode sisipan dengan metode pencincangan. 
Jurnal Media Pertanian Vol. 2 No. 2 Tahun 2017 Hal. 55 - 64

Media Komunikasi Hasil Penelitian dan Review Literatur Bidang Ilmu Agronomi

ISSN print $2503-1279$

ISSN online $2581-1606$

Melalui pemahaman terhadap tabel nilai rata-rata dan hasil analisis statistika $\mathrm{C} / \mathrm{N}$ ternyata proses dekomposisi batang Kelapa sawit hasil replanting metode pencincangan sudah menghasilkan kompos dengan tingkat kematangan yang sesuai dengan standar. Bila disetarakan dengan spesifikasi kualitas kompos bahan organik menurut SNI 19-7030-2004, maka nilai $\mathrm{C} / \mathrm{N}$ proses dekomposisi batang Kelapa sawit hasil replanting metode pencincangan sudah memenuhi standar dengan nilai $\mathrm{C} / \mathrm{N}$ antara 10 sampai 20.

Ukuran partikel batang Kelapa sawit yang lebih kecil karena telah dicincang dibanding yang tidak dicincang pada metode sisipan akan mendorong semikin cepatnya laju dekomposisi. Pengurangan ukuran residu secara fisik mengekspos lebih luas permukaan untuk dekomposisi. Menurut Nurhidayati, dkk. (2008), pengurangan ukuran partikel residu dapat membantu memecahkan dinding sel yang mengandung lignin dan lapisan luar yang mengandung wax, sehingga mengekspos lebih siap sel-sel dan jaringan untuk terdekomposisi.

Lokasi penempatan batang Kalapa sawit juga mempengaruhi aktivitas dekomposisi..Hasil pencincangan batang Kelapa sawit pada metode pencincangan ditumpuk pada tempat-tempat tertentu, berbeda dengan metode sisipan yang hanya dibiarkan dalam bentuk batang yang utuh dan terletak di atas tanah. Menurut Nurhidayati, dkk.(2008), bila residu bahan organik hanya diletakkan di atas tanah, biasanya akan lebih lambat terdekomposisi karena residu-residu ini akan lebih cepat kering akibat terpapar langsung pada cahaya matahari dan temperatur yang tinggi.

Kemasaman $(\mathrm{pH})$ tanah di lokasi pengambilan sampel metode replanting pencincangan mendekati netral (6,0). Menurut Nurhidayati, dkk. (2008), kondisi lingkungan yang sesuai untuk proses dekomposisi dan mineralisasi yang cepat adalah pada $\mathrm{pH}$ mendekati netral. Sebaliknya, $\mathrm{pH}$ tanah di lokasi metode sisipan yang relatif rendah $(4,9)$ mengurangi aktifitas mikroba dekomposer sehingga rasio $\mathrm{C}-\mathrm{N}$ nya belum memenuhi standar karakteristik kematangan kompos.

Rata-rata nilai $\mathrm{C}$ organik antara metode replanting dengan metode pencincangan relatif sama (Tabel 7 dan 8), hal ini diduga disebabkan tingginya kandungan $\mathrm{C}$ pada batang Kelapa sawit dari lokasi replanting sehingga proses dekomposisi berjalan lambat.

\section{Kesimpulan}

\section{KESIMPULAN DAN SARAN}

Berdasarkan hasil penelitian dan pembahasan yang sudah diuraikan, dapat dirumuskan beberapa kesimpulan sebagai berikut ;

1. Proses dekomposisi batang Kelapa sawit hasil replanting metode sisipan berbeda dengan dekomposisi metode pencincangan.

2. Dekomposisi batang Kelapa sawit metode pencincangan menghasilkan nilai C/N 14,24, sesuai dengan spesifikasi kualitas kompos bahan organik menurut SNI 19-7030-2004 (10 sampai 20$)$.

\section{Saran}

Berdasarkan hasil analisis $\mathrm{C} / \mathrm{N}$ dan analisis statistika, maka disarankan agar dilakukan pencincangan (chiping) terhadap batang Kalapa Sawit hasil replanting sisipan di kebun Panca Mulya, kecamatan Sungai Bahar, kabupaten Muaro Jambi. 
Jurnal Media Pertanian Vol. 2 No. 2 Tahun 2017 Hal. 55 - 64

Media Komunikasi Hasil Penelitian dan Review Literatur Bidang Ilmu Agronomi

ISSN print $2503-1279$ ISSN online $2581-1606$

\section{DAFTAR PUSTAKA}

Anonim. 2004. SNI Spesifikasi Kompos dari Sampah Organik Domestik. Standar Nasional Indonesia 19-7030-2004. Badan Standardisasi Nasional, Jakarta.

BPS Provinsi Jambi. 2016. Jambi dalam angka 2016. Badan Pusat Statistik Provinsi Jambi. Jambi

Isroi. 2005. Pengomposan Limbah Padat Organik. Balai Penelitian Bioteknologi Perkebunan Indonesia. Bogor.

Murbandono, H.S.2009. Membuat Kompos. Penebar Swadaya, Jakarta.

Nurhidayati, Istirochah P,Anis S, Djuhari, dan Abd.Basit. 2008. Pertanian Organik. Suatu Kajian Sistem Pertanian Terpadu dan Berkelanjutan. Program Studi Agroteknologi Fakultas Pertanian Universitas Islam Malang. Malang. e-Book

Peraturan Menteri Pertanian RI. 2016. Pedoman Peremajaan Perkebunan Kelapa Sawit. Direktur Jenderal Peraturan Perundang-undangan Kementerian Hukum dan Hak Asasi Manusia Republik Indonesia

Risza, S. 1994. Upaya Peningkatan Produktivitas. Kanisius. Yogyakarta.

Sutarta, E.S. 2015. Teknik Peremajaan Kelapa Sawit. Pusat Penelitian Kelapa Sawit. Medan.

Sutanto, R. 2002. Penerapan Pertanian Organik. Kanisius. Yogyakarta. 